\title{
Meningoencephalitis associated with COVID-19: a systematic review
}

\author{
Ritwick Mondal ${ }^{1}$ - Upasana Ganguly ${ }^{1}$ - Shramana Deb ${ }^{2}$ - Gourav Shome ${ }^{3}$. Subhasish Pramanik ${ }^{1}$. \\ Deebya Bandyopadhyay ${ }^{1}$. Durjoy Lahiri ${ }^{1}$ (i)
}

Received: 14 August 2020 / Revised: 28 September 2020 / Accepted: 19 October 2020 / Published online: 26 December 2020

(c) Journal of NeuroVirology, Inc. 2020

\begin{abstract}
With the growing number of COVID-19 cases in recent times. significant set of patients with extra pulmonary symptoms has been reported worldwide. Here we venture out to summarize the clinical profile, investigations, and radiological findings among patients with SARS-CoV-2-associated meningoencephalitis in the form of a systemic review. This review was carried out based on the existing PRISMA (Preferred Report for Systematic Review and Meta analyses) consensus statement. The data for this review was collected from four databases: Pubmed/Medline, NIH Litcovid, Embase, and Cochrane library and Preprint servers up till 30 June 2020. Search strategy comprised of a range of keywords from relevant medical subject headings which includes "SARS-COV-2," "COVID-19," and "meningoencephalitis." All peer reviewed, case-control, case report, pre print articles satisfying our inclusion criteria were involved in the study. Quantitative data was expressed in mean \pm SD, while the qualitative date in percentages. Paired $t$ test was used for analysing the data based on differences between mean and respective values with a $p<0.05$ considered to be statistically significant. A total of 61 cases were included from 25 studies after screening from databases and preprint servers, out of which 54 of them had completed investigation profile and were included in the final analysis. Clinical, laboratory findings, neuroimaging abnormalities, and EEG findings were analyzed in detail. This present review summarizes the available evidences related to the occurrence of meningoencephalitis in COVID-19.
\end{abstract}

Keywords SARS-CoV-2 · COVID-19 · Coronavirus · Clinical symptoms · Neurological impairments · Meningoencephalitis

\section{Introduction}

The world at present is in combat with COVID-19, appropriately termed by Bill Gates as a "Once-in-a-Century" Pandemic Gates (2020). The dual challenge posed by this pandemic, namely saving lives as well as preventing horizontal transmission, has stretched clinicians to the extreme. With the passage of time, the situation has become more complicated given the unusual clinical manifestation of this

Durjoy Lahiri

dlahiri1988@gmail.com

1 Bangur Institute of Neurosciences, Institute of Post Graduate Medical Education and Research, SSKM Hospital, Kolkata, India

2 S.N. Pradhan Centre for Neuroscience, University of Calcutta, Kolkata, India

3 Department of Microbiology, University of Calcutta, Kolkata, India viral infection. Several extra-pulmonary manifestations of COVID-19 have been brought to attention by treating physicians worldwide. Among these, neuro-invasive potential of SARS-CoV-2 has received significant attention. There is now sufficient body of evidence to support the idea that COVID-19 can have pure neurological presentations and on some occasions, preceding the typical respiratory manifestations (Zubair et al. 2019; Koralnik and Kenneth 2020; Lahiri et al. 2020a). Besides, a myriad of neurological consequences following typical clinical presentation of COVID19 has also been documented across the globe. In sum, neuro COVID as a distinct topic of discussion has been steadily gaining attention over the last couple of months.

Among the central nervous system (CNS) manifestations, impaired consciousness/encephalopathy is a widely reported symptom of COVID-19 Zubair et al. (2019); Encephalopathy and in patients with COVID19: 'Causality or coincidence' Journal of Medical Virology $2020 \mathrm{~d}$ and various possible aetiologies underlying 
this symptom have been scrutinized in literature. It has been widely speculated that the virus gains access into the brain via olfactory bulb and the hypothesis gained substantial support from the observation that anosmia is a fairly consistent symptom of early COVID-19 (Zubair et al. 2019). An alternative proposed route for the virus to invade brain is hematogenous (Zubair et al. 2019). Given the potential of SARS-CoV-2 to invade CNS and also our previous experience with MERS and SARS-CoV, meningoencephalitis in COVID-19 is a duly anticipated clinical feature. Indeed, in the last couple of months, multiple reports of meningoencephalitis associated with COVID19 have surfaced up. These cases not only have encompassed a wide range of clinical presentations but also have documented varied laboratory and imaging results. That said, it can be assumed that in current situation underreporting of cases is a non-negligible issue, and therefore, these cases only represent tip of the iceberg. Nevertheless, an organized summary and critical review of these documents can reveal a wealth of information about the clinical, laboratory, and imaging features of meningoencephalitis in COVID-19.

In this background, we set out to develop a systematic review of meningoencephalitis cases in COVID-19 available in a wide array of databases. Our main objective is to summarize the clinical presentations, laboratory parameters including CSF abnormalities, and brain imaging features of SARS-CoV-2-associated meningoencephalitis. Such a documentation will not only work as a guide to clinicians dealing with COVID-19 patients but also will open up new avenues towards understanding the neuro-invasive potential and routes of this virus.

\section{Methodology}

\section{Design}

This systematic review was conducted by following the Preferred Reporting for Systematic Review and Meta-Analysis (PRISMA) consensus statement (CRD42020185571) (Lahiri et al. 2020b). Studies relevant to the confirmed cases of COVID-19 infection with confirmed or suspected association of meningoencephalitis were included.

\section{Search strategy}

In this systemic review four databases, Pubmed/Medline, NIH LitCovid, Embase, and Cochrane Library, were searched using pre specified searching strategies and this search was concluded on 10 June 2020 . The search strategy consists of variation of keywords of relevant medical subject headings (MeSH) and key words, including "SARS-CoV-2,"
"COVID-19," "coronavirus," "clinical symptoms," "neurological impairments," and "Meningoencephalitis." Severe Acute Respiratory Syndrome Coronavirus (SARS-CoV) and Middle East Respiratory Syndrome Coronavirus (MERS$\mathrm{CoV}$ ) were also included in our search strategy to capture related articles. We also hand searched additional COVID19 specific articles using the reference list of the selected studies, relevant journal websites, and renowned pre-print servers (medRxiv, bioRxiv, pre-preints.org) from 2019 to current date for literature inclusion. To decrease publication bias, we invigilated the references of all studies potentially missed in electrical search. Content experts also searched the grey literature of any relevant articles.

\section{Study selection criteria}

All peer-reviewed, pre-print (not-peer-reviewed) including cohort, case-control studies and case reports which met the pre-specified inclusion and exclusion criteria were included in this study. The PRISMA flow chart for study selection for this current review has been depicted in Fig. 1.

\section{Inclusion criteria}

Studies met the following inclusion criteria were included if (i) conducted for the patients infected with COVID-19 with or suspected meningoencephalitis; (ii) studies registering neurological manifestations of COVID-19 patients were included with encephalitis like symptoms; (iii) parallel studies to look into the detailed distribution and incidences of meningoencephalitis in previous outbreaks, i.e. SARS-CoV, MERS-CoV, and various other coronaviruses, were compared with current pandemic in the discussion section; and (iv) published in the English language. Studies without complete information but met our inclusion criteria were included in the narrative review.

\section{Exclusion criteria}

Studies excluded if COVID-19 was not confirmed among patients and written in languages other than English. We also excluded review papers, viewpoints, commentaries, and studies where no information related to neurological symptoms or meningoencephalitis was reported.

\section{Data extraction}

Prior to the screening process, team of three reviewers (GS, DB, and SD) participated in calibration and screening exercises. First two reviewers (GS and DB) subsequently screened independently the titles and abstracts of all identified citations, and the third reviewer (SD) verified 


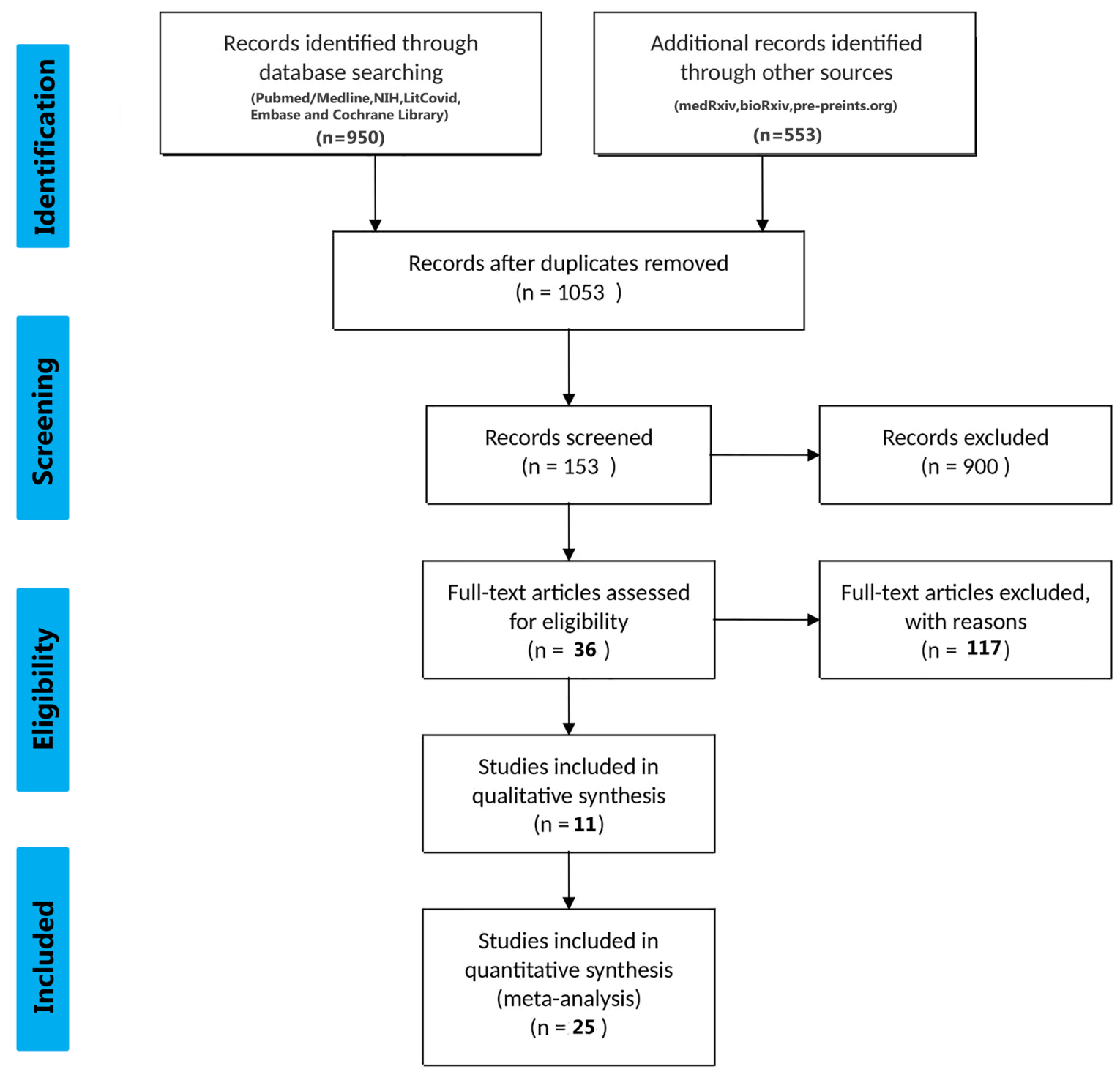

Fig. 1 The PRISMA flow chart for study selection

those citations and screened papers by (GS and DB). Other two reviewers (UG and SA) then retrieved and screened independently the full texts of all citations deemed eligible by the reviewer (SD) on the team and analysed those data. Another reviewer (RM) independently verified these extracted full texts for eligibility towards analysis and designed the overall study structure. The corresponding author (DL) had resolved disagreements whenever necessary and took final decisions regarding the study. Throughout the screening and data extraction process, the reviewers used piloted forms. In addition to the relevant clinical data, the reviewers also extracted data on the following characteristics: study characteristics (i.e. study identifier, study design, setting, timeframe), population characteristics, comparator characteristics, outcomes (qualitative and/or quantitative), clinical factors (definition and measurement methods), reported funding sources and conflict of interests; and study limitations. The Newcastle-Ottawa scale was used to assess the selection procedure, the comparability, and the outcomes of each reviewed study.

\section{Statistical analysis}

Quantitative data were presented using means \pm standard deviation (SDs). Qualitative data were presented as percentage value. Unit discordance among the variables was resolved by converting the variables to a standard unit of measurement. Further, one sample $t$ test was performed 
to find out significant difference between mean value and respective reference value (highest value of the reference range was taken) of each parameter. A value of " $p$ " $<0.05$ was considered as statistically significant. All statistical analyses were performed and analyzed using GraphPad prism (Version 6, San Diego, CA, USA). A meta analysis was planned to analyze the association of the demographic findings, co-morbidities, symptoms, diagnostic parameters, and outcomes with imaging findings but was later omitted due to lack of sufficient data.

\section{Results}

\section{Study characteristics (Table 1)}

A total of around 61 cases were included in the study from 25 different articles coming from both 3 database search and preprint servers. Complete data were available for 54 $(n=54)$ cases, and laboratory findings data was unavailable in 7 cases from Varatharaj et al. (2020). The studies of 54 cases comprised of case reports and original article.

\section{Demography and clinical symptomatology (Tables 2 and 3)}

The selected study comprised of 54 cases with the mean age around $(50.8 \pm 19.09)$ and $35(65 \%)$ male with $19(35 \%)$ female cases were reported for analysis with full data availability. SARS-CoV-2 was primarily detected in nasopharyngeal/oropharyngeal/bronchoalveolar swab (92.6\%), CSF $(5.55 \%)$, and antibody detected in two patients (3.7\%) only. Majority of the reported cases had no travel history (3.7\%) or contact with COVID-19 positive individuals (7.4\%). They had various symptoms ranging from fever, cough, headache, etc. Potent neurological symptoms reported were tonic-clonic seizures (5.55\%), disorientation to time and place $(22.22 \%)$, nuchal rigidity $(9.25 \%)$, limb ataxia (11.11\%), etc. Various kinds of co-morbidities that existed in patients were diabetes mellitus (18.5\%), hypertension (37\%), Obesity (3.7\%), and coronary artery disease (3.7\%) with two special cases of Alzheimer's disease and autism. The patients were hospitalized on $(8.88 \pm 4.094)$ days $(m e a n \pm S D)$ from the onset of the symptoms. Their average days of hospitalization were $(13.83 \pm 7.901)$ days (mean $\pm \mathrm{SD})$.

Table 1 Included studies

\begin{tabular}{|c|c|c|c|c|}
\hline SL. no & Authors & Title of the paper & No. of cases & Type of paper \\
\hline 1 & Po Fung Wong et al. (2020) (UK) & $\begin{array}{l}\text { A case of rhombencephalitis as a rare complication } \\
\text { of acute COVID-19 infection }\end{array}$ & 1 & Lessons of the Month \\
\hline 2 & Adelaide Panariello et al. (2020) (Italy) & $\begin{array}{l}\text { Anti-NMDA receptor encephalitis in a psychiatric } \\
\text { Covid-19 patient: a case report }\end{array}$ & 1 & Letter to Editor \\
\hline 3 & Mohammad Al Olama et al. (2020) (UAE) & $\begin{array}{l}\text { COVID-19-associated meningoencephalitis } \\
\text { complicated } \\
\text { with intracranial hemorrhage: a case report }\end{array}$ & 1 & Case Report \\
\hline 4 & H. Chaumont et al. (2020) (France) & $\begin{array}{l}\text { Acute meningoencephalitis in a patient with } \\
\text { COVID-19 }\end{array}$ & 1 & Letter to Editor \\
\hline 5 & Andrea Pilotto et al. (2020) (Italy) & $\begin{array}{l}\text { COVID-19 impact on consecutive neurological } \\
\text { patients admitted to the emergency department }\end{array}$ & 14 & Original article \\
\hline 6 & Rong Yin et al. (2020) (China) & $\begin{array}{l}\text { Concomitant neurological symptoms observed in a } \\
\text { patient diagnosed with coronavirus disease } 2019\end{array}$ & 1 & Letter to Editor \\
\hline 7 & Gary N. McAbee et al. (2020) (USA) & $\begin{array}{l}\text { Encephalitis associated with COVID-19 infection } \\
\text { in an } 11 \text { year-old child }\end{array}$ & 1 & Letter to Editor \\
\hline 8 & Sandeep Sohal, Mansoor Mosammat (2020) (USA) & COVID-19 presenting with seizures & 1 & Original Article \\
\hline 9 & Rebecca Packwood et al. (2020) (USA) & $\begin{array}{l}\text { An unusual case report of COVID- } 19 \text { presenting } \\
\text { with meningitis symptoms and shingles }\end{array}$ & 1 & Case Report \\
\hline 10 & Charcon Aguilar et al. (2020) (Spain) & $\begin{array}{l}\text { COVID-19: Fever syndrome and neurological } \\
\text { symptoms in a neonate }\end{array}$ & 1 & Letter to Editor \\
\hline 11 & Hale Afshar et al. (2020) (Iran) & $\begin{array}{l}\text { Evolution and resolution of brain involvement } \\
\text { associated with SARS- CoV2 } \\
\text { infection: a close clinical - paraclinical follow up } \\
\text { study of a case }\end{array}$ & 1 & Case Report \\
\hline 12 & Ye et al. (2020) (China) & $\begin{array}{l}\text { Encephalitis as a clinical manifestation of COVID- } \\
19\end{array}$ & 1 & Letter to Editor \\
\hline 13, & Narges Karimi et al. (2020) (Iran) & $\begin{array}{l}\text { Frequent convulsive seizures in an adult patient } \\
\text { with COVID-19: A } \\
\text { Case Report }\end{array}$ & 1 & Case Report \\
\hline
\end{tabular}


Table 1 (continued)

\begin{tabular}{|c|c|c|c|c|}
\hline SL. no & Authors & Title of the paper & No. of cases & Type of paper \\
\hline 14 & Ibrahim Efecan Efe (2020) (Turkey, Germany) & $\begin{array}{l}\text { COVID-19-associated encephalitis mimicking glial } \\
\text { tumor: a case report }\end{array}$ & 1 & Case Report \\
\hline 15 & Duong et al. (2020) (USA) & $\begin{array}{l}\text { Meningoencephalitis without respiratory failure in } \\
\text { a young female patient with COVID-19 infection } \\
\text { in downtown Los Angeles, early April } 2020\end{array}$ & 1 & Letter to Editor \\
\hline 16 & Moriguchi et al. (2020) (Japan) & $\begin{array}{l}\text { A } \\
\text { first case of meningitis/encephalitis associated with } \\
\text { SARS-Coronavirus-2 }\end{array}$ & 1 & Case Report \\
\hline 17 & Misayo Hayashi et al. (2020) (Japan) & $\begin{array}{l}\text { COVID-19-associated mild encephalitis/encepha- } \\
\text { lopathy with a reversible splenial lesion }\end{array}$ & 1 & Letter to Editor \\
\hline 18 & Andrea Pilotto et al. (2020) (Italy) & $\begin{array}{l}\text { Steroid-responsive encephalitis in Covid-19 } \\
\text { disease }\end{array}$ & 1 & Original Article \\
\hline 19 & Dogan et al. (2020) (Turkey) & $\begin{array}{l}\text { Plasmapheresis treatment in COVID-19-related } \\
\text { autoimmune } \\
\text { meningoencephalitis: case series }\end{array}$ & 6 & Original Article \\
\hline 20 & Debaleena Mukherjee et al. (2020) (India) & $\begin{array}{l}\text { Ataxia as a presenting manifestation of COVID } \\
-19 \text { : Report of a single case }\end{array}$ & 1 & Case Report \\
\hline 21 & Raphael Bernard-Valnet et al. (2020) (Switzerland) & $\begin{array}{l}\text { Two patients with acute meningo-encephalitis } \\
\text { concomitant to SARS-CoV-2 infection }\end{array}$ & 2 & Letters to Editor \\
\hline 22 & Mauro Morassi et al. (2020) (Italy) & $\begin{array}{l}\text { Stroke in patients with SARS-CoV-2 infection: } \\
\text { case series }\end{array}$ & 1 & Original Article \\
\hline 23 & Guy Talmor et al. (2020) (USA) & $\begin{array}{l}\text { Nasoseptal flap necrosis after endoscopic skull } \\
\text { base surgery in the setting of SARS-CoV-2/ } \\
\text { COVID-19 }\end{array}$ & 1 & Case Report \\
\hline 24 & Manuel Romero et al. (2020) (Spain) & $\begin{array}{l}\text { Neurologic manifectations in hospitalized patients } \\
\text { in COVID-19 The ALBACOVID registry }\end{array}$ & 1 & Original Article \\
\hline 25 & Varatharaj A et al. (2020) (UK) & $\begin{array}{l}\text { Neurological and neuropsychiatric complica- } \\
\text { tions of COVID-19 in } 153 \text { patients: a UK-wide } \\
\text { surveillance study }\end{array}$ & 7 & Original Article \\
\hline
\end{tabular}

\section{Laboratory findings}

\section{Hematological parameters (Table 4)}

Major cell counts were observed within various patients. Recorded WBC counts in cases $(n=13)$ were $(10.12 \pm 8.33) \times 10^{9}($ mean $\pm \mathrm{SD})$ with a $p=0.734$ and lymphocyte counts observed for six patients $(n=6)$ were $(3.177 \pm 3.06) \times 10^{9}($ mean $\pm S D)$. Elevated levels of C-reactive protein (CRP) among patients $(n=13)$ around $(102 \pm 129.8$; mean $\pm \mathrm{SD})(\mathrm{mg} / \mathrm{L})$ were reported with a $p=0.064$. Moreover, highly significant levels of D-dimer $(\mathrm{ng} / \mathrm{ml})$ in patients $(n=10)$ were observed with a significant $p=0.0186(p<0.05)$.

\section{CSF parameters (Table 4)}

Various CSF parameters under biochemical analysis such as glucose $(\mathrm{mg} / \mathrm{dl})(n=16)$ and protein $(\mathrm{mg} / \mathrm{dl})(n=18)$ were recorded where significant levels of protein $(p=0.00457)$ with elevation of $(73.61 \pm 56.31) \mathrm{mg} / \mathrm{dl}$ from the normal range of (15-45) $\mathrm{mg} / \mathrm{dl}$ was observed. Moreover, certain cell count parameters such as lymphocyte $(n=6)$ was significantly ( $p=0.009)$ higher than the normal range. CSF IgG levels (mg/L) were also found to be significantly $(p=0.0001)$ raised in five patients $(n=5)$.

\section{EEG findings (Table 5)}

EEG findings were reported in 9 cases, and in the remaining 20 cases this parameter was not available for analysis. Bernard Valnet et al. reported EEG from one patient as abundant bursts of anterior low-medium voltage irregular spike-and waves superimposed on an irregularly slowed theta background (Bernard-Valnet et al. 2020), whereas Sohal et al. documented that the patient had six left temporal seizures, left temporal sharp waves which were epileptogenic in nature (Sohal and Mossammat 2020). Pilotto et al. showed generalized slowing with decreased reactivity to acoustic stimuli (Pilotto et al. 2020), and bilateral slowed activity without seizures was 
Table 2 Demographic characteristics of patients hospitalized with COVID-19

\begin{tabular}{|c|c|}
\hline Demographic feature & Total $(n=54)$ \\
\hline Age $(n=26)($ years, mean \pm SD $)$ & $50.8 \pm 19.09$ \\
\hline \multicolumn{2}{|l|}{$\operatorname{Sex}(n(\%))$} \\
\hline Male & $35(65 \%)$ \\
\hline Female & $19(35 \%)$ \\
\hline \multicolumn{2}{|l|}{ Social history $(n(\%))$} \\
\hline Travel history & $2(3.7 \%)$ \\
\hline $\begin{array}{l}\text { Contact with Covid-positive } \\
\text { individuals }\end{array}$ & $4(7.4 \%)$ \\
\hline \multicolumn{2}{|l|}{ Systemic co-morbidities $(n(\%))$} \\
\hline Diabetes mellitus & $10(18.5 \%)$ \\
\hline Hypertension & $20(37 \%)$ \\
\hline Obesity & $2(3.7 \%)$ \\
\hline Coronary artery disease & $2(3.7 \%)$ \\
\hline Chronic kidney disease & $1(1.85 \%)$ \\
\hline Cancer & $1(1.85 \%)$ \\
\hline Substance abuse & $1(1.85 \%)$ \\
\hline Cerebrovascular disease & $3(5.55 \%)$ \\
\hline Hyperlipidemia & $1(3.5 \%)$ \\
\hline Dyslipidemia & $6(11.11 \%)$ \\
\hline Autism & $1(1.85 \%)$ \\
\hline Alzheimer's disease & $1(1.85 \%)$ \\
\hline $\begin{array}{l}\text { Mental retardation (with no } \\
\text { structural abnormalities) }\end{array}$ & $1(1.85 \%)$ \\
\hline $\begin{array}{l}\text { Previous diagnosis of possi- } \\
\text { ble encephalitis and Behcet } \\
\text { disease }\end{array}$ & $1(1.85 \%)$ \\
\hline \multicolumn{2}{|l|}{ SARS-Cov2 detection $(n(\%))$} \\
\hline CSF & $3(5.55 \%)$ \\
\hline $\begin{array}{l}\text { Nasopharyngeal swab/ } \\
\text { Oropharyngeal swab / } \\
\text { Bronchoalveolar lavage }\end{array}$ & $50(92.6 \%)$ \\
\hline $\begin{array}{l}\text { Antibody detection (IgG/ } \\
\text { IgM) }\end{array}$ & $2(3.7 \%)$ \\
\hline $\begin{array}{l}\text { Days between symptom appear- } \\
\text { ance and hospital admission } \\
(n=15] \\
\text { (days, mean } \pm \mathrm{SD})\end{array}$ & $8.88 \pm 4.094$ \\
\hline $\begin{array}{l}\text { Days of hospitalization }(=23) \\
\text { (days, mean } \pm \text { SD) }\end{array}$ & $13.83 \pm 7.901$ \\
\hline
\end{tabular}

$n=$ no. of cases for which data was available for that particular variable. Total number of cases $=54$

reported by Chaumont et al. (2020). Generalized slowing with no epileptic discharges was also documented by Duong et al. (2020). McAbee et al. only reported frontal intermittent delta activity (McAbee et al. 2020). On the other hand Adelaide Panariello et al. reported theta activity at $6 \mathrm{~Hz}$, unstable and non reactive to visual stimuli without significant asymmetries (Panariello et al. 2020). Continuous monitoring with amplitude-integrated
Table 3 Clinical signs and symptoms

\begin{tabular}{|c|c|}
\hline Symptoms & Total $(n=54)$ \\
\hline \multicolumn{2}{|l|}{ General symptoms $(n(\%))$} \\
\hline Fever & $32(59.25 \%)$ \\
\hline Cough & $23(42.6 \%)$ \\
\hline Dyspnoea & $15(27.8 \%)$ \\
\hline Fatigue & $18(33.33 \%)$ \\
\hline Headache & $7(13 \%)$ \\
\hline Breathing difficulty/Shortness of breath & $2(3.7 \%)$ \\
\hline Anosmia & $1(1.85 \%)$ \\
\hline Ageusia & $1(1.85 \%)$ \\
\hline Dysgeusia & $1(1.85 \%)$ \\
\hline Myalgia & $5(9.25 \%)$ \\
\hline Nausea & $1(1.85 \%)$ \\
\hline Dizziness & $3(5.55 \%)$ \\
\hline Diarrhoea & $4(7.40 \%)$ \\
\hline Anorexia & $1(1.85 \%)$ \\
\hline Rhinorrhea & $2(3.7 \%)$ \\
\hline Vomiting & $2(3.7 \%)$ \\
\hline Abdominal pain & $1(1.85 \%)$ \\
\hline Constipation & $1(1.85 \%)$ \\
\hline Respiratory distress & $2(3.7 \%)$ \\
\hline \multicolumn{2}{|l|}{ Neurological symptoms $(n(\%))$} \\
\hline Delirium/Altered mental status & $1(3.5 \%)$ \\
\hline Confusion / Disorientation / Altered HMF & $20(37 \%)$ \\
\hline Focal motor deficits & $12(22.22 \%)$ \\
\hline Seizures & $6(11.11 \%)$ \\
\hline Limb ataxia & $6(11.11 \%)$ \\
\hline Nuchal rigidity & $6(11.11 \%)$ \\
\hline Aphasia & $5(9.25 \%)$ \\
\hline Tonic-clonic seizures & $3(5.55 \%)$ \\
\hline Verbal and motor perseverations & $3(5.55 \%)$ \\
\hline Bilateral grasping & $1(1.85 \%)$ \\
\hline Visual hallucinations & $2(3.7 \%)$ \\
\hline Speech slurring & $2(3.7 \%)$ \\
\hline Kernig's sign & $3(5.55 \%)$ \\
\hline Babinski sign & $1(1.85 \%)$ \\
\hline Chaddock sign & $1(1.85 \%)$ \\
\hline Brudzinski sign & $1(1.85 \%)$ \\
\hline Increased deep tendon reflexes & $2(3.7 \%)$ \\
\hline
\end{tabular}

$n=$ no. of cases for which data was available for that particular variable. Total number of cases $=54$

electroencephalography (EEG) by Charcon Aguilar et al. for $36 \mathrm{~h}$ revealed a continuous background pattern with sleep-wake cycles in the absence of electrical and clinical seizures for a patient (Chacón-Aguilar et al. 2020). Interestingly Morassi et al. reported that on day 4 the EEG showed a normal background in the alpha range $(8 \mathrm{~Hz})$ associated with recurrent sharp slow waves over the left temporal region, which occasionally were seen also on 
Table 4 Clinical and laboratory diagnostic parameters

\begin{tabular}{llll}
\hline Test & Normal value & Mean \pm SD & $p$ value \\
\hline Blood pressure $(\mathrm{mm} \mathrm{Hg})(n=5)$ & & & \\
$\quad$ Systolic pressure & 120 & $128.2 \pm 22.68$ & 0.4641 \\
$\quad$ Diastolic pressure & 80 & $78.60 \pm 9.12$ & 0.3513 \\
Heart rate (beats/min) $(n=5)$ & 82 & $93 \pm 4.41$ & $0.004^{*}$ \\
O $_{2}$ saturation $($ at room air) $(\%)(n=8)$ & 97 & $93.63 \pm 3.88$ & $0.0120^{*}$ \\
Respiratory rate (breaths per minute) $(n=8)$ & 20 & $25.33 \pm 7.448$ & 13.98 \\
WBC $(n=13)$ & $(4-11) \times 10^{9}$ & $(10.12 \pm 8.33) \times 10^{9}$ & 0.734 \\
Lymphocyte $(n=6)$ & $(1.5-3.5) \times 10^{9}$ & $(3.177 \pm 3.06) \times 10^{9}$ & 0.8717 \\
Platelets $(n=6)$ & $(150-450) \times 10^{9}$ & $(326.4 \pm 258.8) \times 10^{9}$ & 0.345 \\
C-reactive protein $(\mathrm{mg} / \mathrm{L})(n=13)$ & $<10 \mathrm{mg} / \mathrm{L}$ & $(102 \pm 129.8)$ & 0.064 \\
D-dimer $(\mathrm{ng} / \mathrm{ml})(n=10)$ & $500 \mathrm{ng} / \mathrm{ml}$ & $(3970 \pm 3217)$ & $0.0186^{*}$ \\
LDH $(\mathrm{U} / \mathrm{L})(n=13)$ & $140-280$ & $642 \pm 494.9$ & 0.059 \\
CSF parameters & & & \\
$\quad$ Protein $(\mathrm{mg} / \mathrm{dl})(n=18)$ & $15-45$ & $73.61 \pm 56.31$ & $0.00457^{*}$ \\
$\quad$ Glucose $(\mathrm{mg} / \mathrm{dl})(n=16)$ & $45-80$ & $95.24 \pm 42.16$ & 0.2170 \\
$\quad$ Lymphocyte $(n=6)$ & $62 \%$ & $95.33 \pm 5.68$ & $0.009^{*}$ \\
IgG $(\mathrm{mg} / \mathrm{L})(n=5)$ & $0-81$ & $4.91 \pm 1.32$ & $<0.0001^{*}$ \\
IgG index $(\mathrm{mg} / \mathrm{L})(n=5)$ & $0-0.7$ & $1.50 \pm 1.84$ & 0.4479 \\
AlbQ $(n=5)$ & 1.85 & $10.32 \pm 3.65$ & $<0.0001^{*}$ \\
\hline
\end{tabular}

$n=$ no. of cases for which data was available for that particular variable. Total number of cases $=54$

*Indicates $p<0.05$ which is considered statistically significant the right homologous regions. On day 10, a new EEG excluded non-convulsive status epilepticus, while showing persistence of sharp slow waves, mainly over the left hemispheric regions for the same patient (Morassi et al. 2020).

\section{Neuroimaging findings (Table 6)}

Neuroimaging findings were reported in 20 studies consisting of 26 cases, and in the remaining 35 cases brain scans were not available. Among the imaging modalities, CT scan and MRI were done in 10 and 16 cases respectively. Vessel imaging was available in 1 case (CTA). In majority of the cases neuroimaging finding did not reveal any abnormality $(13 / 26,50 \%)$. At least one radiological abnormality was reported in 14 cases $(14 / 26,53.84 \%)$. Among the abnormal MRI findings, T2/T2 FLAIR hyperintensity in MRI brain was the most frequently reported $(6 / 16,37.5 \%)$. Noteworthy, temporal lobe was the commonest site of involvement in MRI brain ( 6 cases). Stroke-like findings manifested by hypodensity on CT scan (3 cases) and diffusion restriction in MRI ( 2 cases) were also observed. Beaded appearance on CT angiography was reported in 1 case associated with extradural haemorrhage.

\section{Treatment and outcome (Tables 7 and 8)}

Treatment were carried out with various drugs such as Hydroxycholoroquine (74\%), Azithromycin (29.41\%),
Antiretroviral drugs (Lopinavir/Ritonavir/Darunavir/ Cobisitat) (55.55\%), and Favipiravir (14.81\%) or used in multidrug therapy $(81.48 \%)$. Various procedures such as Plasmapheresis $(11.11 \%)$ and invasive ventilation $(26 \%)$ were used along with many other therapies on the patients. Frequently used multidrug therapy includes Hydroxycholorquine along with Antivirals (57.40\%). Majority of the patients recovered (72\%) with a mortality of (17\%), and six patients were still under treatment during the period of study.

\section{Discussion}

In the index paper we attempted to summarize the clinical features, laboratory parameters, EEG findings, and imaging abnormalities in patients presenting with confirmed SARS-CoV-2 infection and clinical/confirmed meningoencephalitis. Of note, a fair number of cases with meningoencephalitic presentation of COVID-19 have already surfaced up even in the background of possible underreporting because of the ongoing pandemic. We found description of 61 such cases in the available literature so far among which 54 were included in the final analysis as detailed data for the remaining 7 cases were not available. To the best of our knowledge, this is the first ever attempt to explore meningoencephalitis in COVID-19 by means of systematic review of both peer reviewed as well 
Table 5 EEG findings

\begin{tabular}{|c|c|c|}
\hline Authors & $\begin{array}{l}\text { Number } \\
\text { of cases }\end{array}$ & EEG findings \\
\hline Wong et al. (2020) & 1 & NA \\
\hline Panariello et al. (2020) & 1 & Theta activity at $6 \mathrm{~Hz}$, unstable, non reactive to visual stimuli. No significant asymmetries were seen \\
\hline Al-olama et al. (2020) & 1 & NA \\
\hline Chaumont et al. (2020) & 1 & Bilateral slowed activity without seizures \\
\hline Pilotto, et al. (2020) & 25 & NA \\
\hline Yin et al. (2020) & 1 & NA \\
\hline McAbee et al. (2020) & 1 & Frontal intermittent delta activity \\
\hline Sohal and Mossammat (2020) & 1 & Six left temporal seizures, left temporal sharp waves which were epileptogenic \\
\hline Packwood et al. (2020) & 1 & NA \\
\hline Chacón-Aguilar et al. (2020) & 1 & $\begin{array}{l}\text { Continuous monitoring with amplitude-integrated electroencephalography (EEG) for } 36 \mathrm{~h} \text { revealed } \\
\text { a continuous background pattern with sleep-wake cycles in the absence of electrical and clinical } \\
\text { seizures }\end{array}$ \\
\hline Afshar et al. (2020) & 1 & NA \\
\hline Ye et al. (2020) & 1 & NA \\
\hline Narges Karimi et al. & 1 & NA \\
\hline Efe et al. (2020) & 1 & NA \\
\hline Duong et al. (2020) & 1 & Generalized slowing with no epileptic discharges \\
\hline Moriguchi et al. (2020) & 1 & NA \\
\hline Hayashi et al. (2020) & 1 & NA \\
\hline Pilotto et al. (2020) & 1 & Generalized slowing with decreased reactivity to acoustic stimuli \\
\hline Dogan et al. (2020) & 6 & NA \\
\hline Mukherjee et al. (2020) & 1 & NA \\
\hline Bernard-Valnet et al. (2020) & 2 & $\begin{array}{l}\text { Patient 1: abundant bursts of anterior low-medium voltage irregular spike-and waves superimposed on } \\
\text { an irregularly slowed theta background } \\
\text { Patient 2: NA }\end{array}$ \\
\hline Morassi et al. (2020) & 1 & $\begin{array}{l}\text { On day } 4 \text {, EEG showed a normal background in the alpha range }(8 \mathrm{~Hz}) \text {, associated with recurrent } \\
\text { sharp slow waves over the left temporal region, which occasionally were seen also on the right } \\
\text { homologous regions } \\
\text { On day } 10 \text {, a new EEG excluded non-convulsive status epilepticus, while showing persistence of sharp } \\
\text { slow waves, mainly over the left hemispheric regions }\end{array}$ \\
\hline Talmor et al. (2020) & 1 & NA \\
\hline Romero-Sánchez et al. (2020) & 1 & NA \\
\hline Varatharaj et al. (2020) & 7 & NA \\
\hline
\end{tabular}

as pre-print data. The present study is important in terms of advancing our knowledge and understanding related to the neuro-invasive potential of SARS-CoV-2 which primarily is considered a respiratory pathogen.

Coronaviruses have been detected in both cerebrum and cerebrospinal fluid of individuals with seizures, encephalitis, and encephalomyelitis(Varatharaj et al. 2020).According to different case reports of MERS coronavirus, neurological manifestations such as meningoencephalitis, hyporeflexia, and ataxia have been found (Bohmwald et al. 2018). It was also shown that neuronal infection leads to death in hACE2 (full form) transegnic mice infected with SARS-CoV (Kim et al. 2017 Jul). Accumulative evidences reflect that virus has been detected in cerebrum (Netland et al. 2008) as well as in CSF in case of SARS-CoV infection (Ding et al. 2004). Other coronaviruses such as $\mathrm{HCoV-OC43} \mathrm{under} \mathrm{the} \mathrm{genera} \mathrm{of} \mathrm{Betacoronaviridae} \mathrm{is}$ found to be associated with viral encephalitis (Lau et al. 2004) and acute disseminated encephalomyelitis (Morfopoulou et al. 2020). Similarly, CoV-NL63 under the genera of Alphacoronaviridae causes acute encephalitis with self-limiting CNS infection (Yeh et al. 2004). Viral encephalitis caused by coronavirus infection was reported among paediatric population with respiratory tract infection (Schattner et al. 1032). Overall, the predisposition of various coronaviruses towards neurotropism seems evident and very much happening which is generating a major concern for virus mediated encephalitis. 
Table 6 Neuroimaging findings

\begin{tabular}{|c|c|c|}
\hline SL. no & Imaging type & Findings \\
\hline 1 & CT & $\begin{array}{l}\text { NAD- [Panariello et al. 2020, Yin et al. } \\
\text { 2020, McAbee et al. 2020, Ye et al. } \\
\text { 2020, Duong et al. 2020, Pilotto et al. } \\
\text { 2020, Mukhergee et al. 2020] } \\
\text { Haemorrhagic- } \\
\text { Frontal EDH [Al-olama et al. 2020] } \\
\text { Ischemic- } \\
\text { Right caudate nucleus [Morassi et al. } \\
\text { 2020] } \\
\text { Chronic microvascular change [Sohal and } \\
\text { Mossamat 2020] }\end{array}$ \\
\hline 2 & MRI & $\begin{array}{l}\text { NAD-[ref-Chaumont et al. 2020, Karimi } \\
\text { et al. 2020, Dogan et al. 2020 (case no } \\
\text { 3,4,5), Bernard-Valnet et al. 2020] } \\
\mathrm{T}_{2} \text { [Wong et al. 2020,Afshar et al. 2020, } \\
\text { Efe et al. 2020] or T } 2 \text { /FLAIR hyper- } \\
\text { intensity-[ref-Efe et al. 2020, Mori- } \\
\text { guchi et al. 2020, Morassi et al. 2020, } \\
\text { Ramero-Sanchez et al. 2020] } \\
\text { Encephalitis like feature (hyperintensity, } \\
\text { enhancement, haemorrhage) [Dogan } \\
\text { et al. 2020 (case nos 1, 2, 6)] } \\
\text { DWI Restriction/ADC hypodensity } \\
\text { [Moriguchi et al. 2020, Hayashi et al. } \\
\text { 2020] }\end{array}$ \\
\hline 3 & Angiography & $\begin{array}{l}\text { CTA } \\
\text { Beaded appearance-[Al-aloma et al. } \\
2020] \\
\text { MRA } \\
\text { NA }\end{array}$ \\
\hline 5 & MRS & Choline peak-[Efe et al. 2020] \\
\hline 4 & Not available & $\begin{array}{l}\text { [Pilotto et al. 2020, Packwood et al. } 2020 \\
\text { Chacon-Aguillar 2020, Talmor et al. } \\
\text { 2020, Romrero-Sanchez et al. 2020, } \\
\text { Varatharaj et al. 2020] }\end{array}$ \\
\hline
\end{tabular}

CT computed tomography, MRI magnetic resonance imaging, MRS magnetic resonance spectroscopy, $N A D$ no appreciable disease, FLAIR hyperintensity fluid attenuated inversion recovery hyperintensity, $D W I$ diffusion-weighted imaging, $A D C$ apparent diffusion coefficient, CTA computed tomography angiography, MRA magnetic resonance angiography

Analysis of the demographic parameters reveals that mean age of the patients with COVID-19-related meningoencephalitis was $(50.8 \pm 19.09)$ years with males being more commonly affected (70\%). Mean latency between symptom onset and hospital admission was close to 9 days, while mean number of days of hospital stay was approximately 14 days. Majority of the documented patients had co-morbidities with diabetes mellitus and hypertension being most frequent. Among the general symptoms, fever was by far the commonest followed by cough. Notably, anosmia and ageusia (commonly
Table 7 Treatment and outcome

\begin{tabular}{|c|c|}
\hline \multicolumn{2}{|l|}{ Combination therapy } \\
\hline Multidrug Therapy & $44(81.48 \%)$ \\
\hline $\begin{array}{l}\text { Most common multidrug (hydroxychloroquine and } \\
\text { antivirals) }\end{array}$ & $31(57.40 \%)$ \\
\hline \multicolumn{2}{|l|}{ Therapeutics } \\
\hline Hydroxychloroquine (HCQ) & $40(74 \%)$ \\
\hline $\begin{array}{l}\text { Antivirals (Lopinavir/Ritonavir/Darunavir/Cobisi- } \\
\text { tat) }\end{array}$ & $30(55.55 \%)$ \\
\hline Azithromycin (AZT) & $10(29.41 \%)$ \\
\hline Remdesivir & $1(1.85 \%)$ \\
\hline Favipiravir (FAV) & $8(14.81 \%)$ \\
\hline Ceftriaxone (CEF) & $5(9.25 \%)$ \\
\hline Ganciclovir & $1(1.85 \%)$ \\
\hline Meropenem & $2(3.7 \%)$ \\
\hline Amoxicillin & $4(7.47 \%)$ \\
\hline Acyclovir & $7(13 \%)$ \\
\hline Arbidol & $1(1.85 \%)$ \\
\hline Ribavirin & $1(1.85 \%)$ \\
\hline Vancomycin & $4(7.47 \%)$ \\
\hline Plasmapheresis & $6(11.11 \%)$ \\
\hline Invasive ventilation & $14(26 \%)$ \\
\hline Non Invasive ventilation & $5(9.25 \%)$ \\
\hline IVIG & $6(11.11 \%)$ \\
\hline Steroids & $16(30 \%)$ \\
\hline Mannitol infusion & $1(1.85 \%)$ \\
\hline \multicolumn{2}{|l|}{ Outcome } \\
\hline Recovery rate & $39(72 \%)$ \\
\hline Still in treatment & $6(11.11 \%)$ \\
\hline Mortality rate & $9(17 \%)$ \\
\hline
\end{tabular}

considered as markers of neuro-invasion) were reported in uncommonly. In contrast, diarrhoea was relatively common $(7.40 \%)$ among the general symptoms. Respiratory distress was reported in $2(3.7 \%)$ of the documented cases.

Various neurological symptoms were reported in meningoencephalitis associated with SARS-CoV-2 infection. Confusion or disorientation to time and place or altered mental status was the most frequently reported symptom accounting for $22.22 \%$ of the cases. It may therefore be assumed that in places reporting high incidence of COVID-19, confusion or disorientation may prompt investigation for detection of SARS-CoV-2. While the classic Kernig's and Brudzinski's signs were not frequently documented, nuchal rigidity has been more commonly $(9.25 \%)$ observed. Limb ataxia was reported in around $11 \%$ of the cases including the case reported by one of the authors of the present review. Other less reported neurological symptoms include tonic clonic seizures, slurred speech, 
Table 8 Drug dosages with duration

\begin{tabular}{|c|c|c|c|c|}
\hline \multirow[t]{2}{*}{ Serial no } & \multirow[t]{2}{*}{ Authors } & \multicolumn{3}{|l|}{ Treatment } \\
\hline & & Drugs & Dose & Duration \\
\hline \multirow[t]{3}{*}{1} & \multirow[t]{3}{*}{ Po Fung Wong et al. (2020) } & Amoxicillin (oral) & $500 \mathrm{mg}$ & Three times per day \\
\hline & & Paracetamol (oral) & $1 \mathrm{~g}$ & Four times per day \\
\hline & & Gabapentin (oral) at discharge & $300 \mathrm{mg}$ & Twice per day \\
\hline 2 & Adelaide Panariello et al. (2020) & $\begin{array}{l}\text { Haloperidol, promazine, intranasal mida- } \\
\text { zolam, oral quetiapine with no clinical } \\
\text { response. Antibiotic prophylactic } \\
\text { therapy was started. } \\
\text { High doses of dexamethasone and IVIG } \\
\text { were administered. }\end{array}$ & NA & NA \\
\hline 3 & Al Olama et al. (2020) & NA & NA & NA \\
\hline \multirow[t]{3}{*}{4} & \multirow[t]{3}{*}{ Chaumont et al. (2020) } & Acyclovir infusions & NA & Three days \\
\hline & & Hydroxychloroquine sulphate & $200 \mathrm{mg}$ & 3 times per day for 7 days \\
\hline & & Azithromycin & $250 \mathrm{mg}$ & Once daily for 7 days \\
\hline 5 & Andrea Pilotto et al. (2020) & NA & NA & NA \\
\hline 6 & Rong Yin et al. (2020) & $\begin{array}{l}\text { Arbidol, } \\
\text { Ribavirin antiviral therapy, } \\
\text { traditional Chinese medicine }\end{array}$ & NA & NA \\
\hline 7 & Gary McAbee et al. (2020) & NA & NA & NA \\
\hline 8 & $\begin{array}{l}\text { Sandeep Sohal and Mansoor Mosam- } \\
\text { mat (2020) }\end{array}$ & $\begin{array}{l}\text { Hydroxychloroquine, Azithromycin, } \\
\text { Vancomycin, } \\
\text { Piperacillin tazobactam, } \\
\text { Levetiracetam, } \\
\text { Valproate }\end{array}$ & NA & NA \\
\hline \multirow[t]{4}{*}{9} & \multirow[t]{4}{*}{ Rebecca Packwood et al. (2020) } & $\begin{array}{l}\text { Acyclovir, } \\
\text { Vancomycin, } \\
\text { Ceftriaxone, } \\
\text { Doxycycline }\end{array}$ & NA & NA \\
\hline & & Lopinavir/Ritonavir & NA & NA \\
\hline & & Hydroxychloroquine and Azithromycin & NA & 6 day course \\
\hline & & Remdesivir & NA & NA \\
\hline 10 & Charcon Aguilar et al. (2020) & NA & NA & NA \\
\hline \multirow[t]{5}{*}{11} & \multirow[t]{5}{*}{ Hale Afshar et al. (2020) } & $\begin{array}{l}\text { Broad spectrum IV antibiotics: } \\
\text { Meropenem } \\
\text { Levofloxacin } \\
\text { Linezolide }\end{array}$ & $\begin{array}{l}1 \mathrm{~g} \\
750 \mathrm{mg} \\
600 \mathrm{mg}\end{array}$ & $\begin{array}{l}\text { Thrice daily } \\
\text { Daily } \\
\text { Twice daily }\end{array}$ \\
\hline & & $\begin{array}{l}\text { Hydroxychloroquine } \\
\text { Atazanavir }\end{array}$ & $\begin{array}{l}400 \mathrm{mg} \\
200 \mathrm{mg} \\
400 \mathrm{mg}\end{array}$ & $\begin{array}{l}\text { Twice for first day } \\
\text { Twice } \\
\text { Daily }\end{array}$ \\
\hline & & IVIG & $\begin{array}{l}25 \mathrm{~g} / \mathrm{day} \\
\text { later } 3 \mathrm{~g} / \mathrm{kg} \text { body } \\
\text { weight }(250 \mathrm{~g} \\
\text { total })\end{array}$ & 3 days \\
\hline & & Levetiracetam (IV) & $500 \mathrm{mg}$ & Twice daily \\
\hline & & Methylprednisolne (IV) & $500 \mathrm{mg} /$ day & 6 days \\
\hline 12 & Ye et al. (2020) & $\begin{array}{l}\text { Arbidol, } \\
\text { Mannitol infusion }\end{array}$ & NA & NA \\
\hline \multirow[t]{3}{*}{13} & \multirow[t]{3}{*}{ Narges Karimi et al. (2020) } & $\begin{array}{l}\text { Phenytoin (IV), } \\
\text { Levetiracetam (IV) }\end{array}$ & & \\
\hline & & Chloroquine & $200 \mathrm{mg}$ & Twice daily \\
\hline & & Lopinavir/Ritonavir & $400 / 100 \mathrm{mg}$ & Twice daily \\
\hline 14 & Ibrahim Efecan Efe et al. (2020) & NA & NA & NA \\
\hline
\end{tabular}


Table 8 (continued)

\begin{tabular}{|c|c|c|c|c|}
\hline \multirow[t]{2}{*}{ Serial no } & \multirow[t]{2}{*}{ Authors } & \multicolumn{3}{|l|}{ Treatment } \\
\hline & & Drugs & Dose & Duration \\
\hline \multirow[t]{4}{*}{15} & \multirow[t]{4}{*}{ Duong et al. (2020) } & $\begin{array}{l}\text { Antibiotics: } \\
\text { Vancomycin, } \\
\text { Ceftriaxone }\end{array}$ & NA & 3 days \\
\hline & & Acyclovir & NA & NA \\
\hline & & Anti-epileptics (not mentioned) & NA & NA \\
\hline & & Hydroxychloroquine & NA & NA \\
\hline 16 & Moriguchi et al. (2020) & $\begin{array}{l}\text { Ceftriaxone (IV), } \\
\text { Vancomycin (IV), } \\
\text { Acyclovir (IV), } \\
\text { Steroids (IV) } \\
\text { Favipiravir (IV) }\end{array}$ & NA & $\begin{array}{l}\text { NA } \\
10 \text { days }\end{array}$ \\
\hline \multirow[t]{2}{*}{17} & \multirow[t]{2}{*}{ Misayo Hayashi et al. (2020) } & Sulbactam/ampicillin & $1.5 \mathrm{~g}$ & Twice per day \\
\hline & & $\begin{array}{l}\text { Favipiravir, } \\
\text { Corticosteroid pulse, } \\
\text { Ciclesonide, } \\
\text { Meropenem }\end{array}$ & NA & NA \\
\hline \multirow[t]{2}{*}{18} & \multirow[t]{2}{*}{ Pilotto et al. (2020) } & $\begin{array}{l}\text { Lopinavir/Ritonavir } \\
\text { Hydroxychloroquine }\end{array}$ & $\begin{array}{l}400 / 100 \mathrm{mg} \\
200 \mathrm{mg}\end{array}$ & $\begin{array}{l}\text { Twice daily } \\
\text { Twice daily }\end{array}$ \\
\hline & & $\begin{array}{l}\text { High dose IV steroid: } \\
\text { Methylprednisolone }\end{array}$ & $1 \mathrm{~g} /$ day & 5 days \\
\hline 19 & Dogan et al. (2020) & $\begin{array}{l}\text { Lopinavir/Ritonavir, } \\
\text { Azithromycin, } \\
\text { Ceftriaxone, } \\
\text { Hydroxychloroquine, } \\
\text { Favipiravir, } \\
\text { Plasmapheresis cycles }\end{array}$ & NA & NA \\
\hline 20 & Debaleena Mukherjee et al. (2020) & $\begin{array}{l}\text { Intravenous antibiotics and other sup- } \\
\text { portive therapy }\end{array}$ & NA & NA \\
\hline \multirow[t]{2}{*}{21} & \multirow[t]{2}{*}{ Raphael Bernard-Valnet et al. (2020) } & $\begin{array}{l}\text { Patient 1: } \\
\text { Clonazepam and Valproate (IV) }\end{array}$ & NA & NA \\
\hline & & $\begin{array}{l}\text { Patient } 2 \text { : } \\
\text { Ceftriaxone, } \\
\text { Amoxicillin, } \\
\text { Acyclovir }\end{array}$ & NA & NA \\
\hline 22 & Morassi et al. (2020) & NA & NA & NA \\
\hline 23 & Guy Talmor et al. (2020) & $\begin{array}{l}\text { Azithromycin, } \\
\text { Hydroxychloroquine }\end{array}$ & NA & NA \\
\hline \multirow[t]{4}{*}{24} & \multirow[t]{4}{*}{ Romero Sanchez (2020) } & $\begin{array}{l}\text { Most commonly used combination: } \\
\text { Hydroxychloroquine, } \\
\text { Lopinavir/Ritonavir, } \\
\text { N-acetylcysteine, } \\
\text { Azithromycin }\end{array}$ & NA & NA \\
\hline & & $\begin{array}{l}\text { Emtricitabine/Tenofovir or Ribavirin } \\
\text { (replacing Lopinavir/Ritonavir) }\end{array}$ & NA & NA \\
\hline & & $\begin{array}{l}\text { Antibiotics: } \\
\text { Levofloxacin, } \\
\text { Doxycycline, } \\
\text { Ceftriaxone, } \\
\text { Teicoplanin }\end{array}$ & & \\
\hline & & $\begin{array}{l}\text { Corticosteroid IV: } \\
\text { Methylprednisolone }\end{array}$ & $\begin{array}{l}125 \mathrm{mg} \\
250 \mathrm{mg} \\
>250 \mathrm{mg}\end{array}$ & NA \\
\hline
\end{tabular}


Table 8 (continued)

\begin{tabular}{|c|c|c|c|c|}
\hline \multirow[t]{2}{*}{ Serial no } & \multirow[t]{2}{*}{ Authors } & \multicolumn{3}{|l|}{ Treatment } \\
\hline & & Drugs & Dose & Duration \\
\hline & & $\begin{array}{l}\text { Immunomodulatory therapy: } \\
\text { Beta-interferon, } \\
\text { Baricitinib, } \\
\text { IVIG, } \\
\text { Anakinra }\end{array}$ & NA & NA \\
\hline 25 & $\begin{array}{l}\text { Andrea Pilotto et al. (2020) } \\
\text { [The clinical spectrum of encephalitis in } \\
\text { COVID-19 disease: } \\
\text { the ENCOVID multicentre study] }\end{array}$ & $\begin{array}{l}\text { Hydroxychloroquine, } \\
\text { Antiviral }\end{array}$ & NA & NA \\
\hline 26 & Vartharaj et al. (2020) & NA & NA & NA \\
\hline
\end{tabular}

and cognitive difficulties such as verbal and motor perseveration. SARS-CoV-2 detection in CSF was reported in only 3 cases, whereas majority (92.6\%) of the patients were diagnosed based on nasopharyngeal swab/oropharyngeal swab/bronchoalveolar lavage testing.

Among the clinical signs pertaining to general survey, tachycardia and reduced oxygen saturation were common findings. Analysis of blood parameters reveal raised CRP, D-dimer, and LDH were prominent findings, while occurrence of lymphopenia or leucopenia did not reach statistical significance. CSF parameters often give valuable insight to the treating clinicians when faced with cases of meningoencephalitis. CSF parameters in COVID19-associated meningoencephalitis raised protein and increased lymphocyte count as the most notable observations. Therefore, it can be assumed that brain infection in the background of SARS-CoV-2 infection may lead to CSF pleocytosis with lymphocytic predominance accompanied by significant level of rise in CSF protein, both pointing towards intra-thecal inflammation. In addition, while there was documented dip in CSF IgG levels, the IgG index did not deviate much from the normal limits, which may be a reflection of hypoglobulinemia resulting from lymphopenia (Li et al. 2016).

Among the abnormal EEG findings documented in COVID-19 encephalitis, focal epileptiform discharges and generalized slowing are most notable. While focal discharges may signify the occurrence of focal convulsions, generalized slowing is commensurate with the high frequency of altered mental status observed thus far. In short, EEG findings in COVID-19-related meningoencephalitis are mostly non-specific and may indicate ensuing encephalopathy in majority of the cases.

Majority of the patient's brain scans were found devoid of any abnormality. However, among those with abnormal brain scans, a wide range of structural lesions have been observed. The commonest abnormality reported was $\mathrm{T} 2 /$ FLAIR hyper-intensity affecting the temporal lobes. Among the viral causes of temporal lobar hyperintensity, HSV is the forerunner followed by CMV, while anti-NMDAR related autoimmune encephalitis frequently presents temporal lobar changes (Prasad, 1982; Sureka \& Jakkani, 2012). In addition, stroke-like presentations have also been noted which are characterized by restricted diffusion in DWI.

It must also be admitted that at least 2 cases of encephalitis compiled in the present series refer to underlying autoimmune pathogenesis mechanisms. While the case reported by Panariello et al. (2020) has mentioned about the detection of anti NMDAR antibody in association with encephalitis, Pilotto et al. (2020) has described a steroid responsive encephalitis again pointing towards immune pathogenesis. Therefore, it may be speculated that several cases of meningoencephalitis related to COVID-19 may not actually reflect direct viral invasion of CNS. Post-/para-infectious immune pathologies might come into play in some of the clinical presentations. As the reporting of cases would start rising, similar reports are supposed to surface up more frequently.

As far as the treatment is concerned, more than $74 \%$ patients have received therapy with HCQ, while significant proportion of patients received azithromycin, favipiravir, and acyclovir. In fact, almost all the patients were on multi-drug regimen as was documented in this review. Reported mortality rate in COVID-19 encephalitis is $17 \%$. Majority (72\%) of the affected patients experienced recovery and around 1/9th were still under treatment at the time of drafting this review.

\section{Conclusion}

In this systematic review we observe that quite a few reports of meningoencephalitis associated with COVID19 are already available in recent literature even in the 
face of possible under-reporting in contrast to the earlier epidemics of MERS and SARS-CoV. Various clinical presentations have surfaced up among which confusion or disorientation is the most frequent. Among the laboratory parameters, raised CRP and D-dimer are most prominent findings. Analysis of CSF parameters reveals that high protein and lymphocytic pleocytosis are the most observable abnormalities. Focal epileptiform discharges and slowing of background are common EEG abnormalities observed in COVID-19-related meningoencephalitis. A myriad of radiological abnormalities have been observed of which temporal lobar hyper-intensity and diffusion restriction are common. This review has attempted to provide a basic outline of COVID-19-related meningoencephalitis from a clinician's perspective. Hopefully with increment in reporting of neurological manifestations of COVID-19, a clearer picture will become available towards the future.

Acknowledgements We are sincerely thankful to Rohan Sarkhel (Department of Computer Science Engineering,Maulana Abul Kalam Azad University, India) for preparing illustration for this paper.

Authors' contributions RM was involved in study planning, data extraction, and primary draft writing; UG was involved in data extraction, analysis, and primary draft writing; SD participated in data extraction, data analysis, and primary draft writing; GS was involved in data extraction, data analysis, and primary draft writing; SP was involved in data analysis and primary draft writing; DB participated in data extraction and primary daft writing; DL was involved in study planning; data extraction, writing primary draft, and critically revising the whole manuscript.

\section{Compliance with ethical standards}

Conflict of interest The authors declare that they have no conflict of interest.

\section{References}

Afshar H, Yassin Z, Kalantari S et al (2020) Evolution and resolution of brain involvement associated with SARS-CoV2 infection: a close clinical-paraclinical follow up study of a case. Mult Scler Relat Disord. 43:102216

Al-olama M, Rashid A, Garozzo D et al (2020) COVID-19-associated meningoencephalitis complicated with intracranial hemorrhage: a case report. ActaNeurochir 162:1495-1499

Bernard-Valnet R, Pizzarotti B, Anichini A et al (2020) Two patients with acute meningoencephalitis concomitant with SARS-CoV-2 infection. Eur J Neurol. https://doi.org/10.1111/ene.14298

Bohmwald K, Gálvez NMS, Ríos M, Kalergis AM et al (2018) Neurologic alterations due to respiratory virus infections. Front Cell Neurosci 12:386

Chacón-Aguilar R, Osorio-Cámara JM, Sanjurjo-Jimenez I et al (2020) COVID-19: fever syndrome and neurological symptoms in a neonate. Anales de Pediatría 92:373-374

Chaumont H, Etienne P, Roze E et al (2020) Acute meningoencephalitis in a patient with COVID-19. Revue Neurologique 176:519-521
Ding Y, He L, Zhang Q et al (2004) Organ distribution of severe acute respiratory syndrome (SARS) associated coronavirus (SARS$\mathrm{CoV}$ ) in SARS patients: implications for pathogenesis and virus transmission pathways. J Pathol 203(2):622-630. https://doi. org/10.1002/path.1560

Dogan L, Kaya D, Sarikaya T et al (2020) Plasmapheresis treatment in COVID-19-related autoimmune meningoencephalitis: case series. Brain BehavImmun 87:155-158

Duong L, Xu P, Liu A et al (2020) Meningoencephalitis without respiratory failure in a young female patient with COVID-19 infection in Downtown Los Angeles, early April 2020. Brain Behav Immun 87:33

Efe IE, Aydin OU, Alabulut A, Celik O, Aydin K et al (2020) COVID19-associated encephalitis mimicking glial tumor. World Neurosurg. 140:46-48

Gates B (2020) Responding to Covid-19-a Once-in-a-Century pandemic? N Engl J Med. https://doi.org/10.1056/NEJMp2003762

Hayashi M, Sahashi Y, Baba Y, Okura H, Shimohata T et al (2020) COVID-19-associated mild encephalitis/encephalopathy with a reversible splenial lesion. J Neurol Sci. 415:116941

Karimi N, Razavi AS, Rouhani N et al (2020) Frequent convulsive seizures in an adult patient with COVID-19: a case report. Iran Red Crescent Med. 22:e102828

Kim J-E, Heo J-H, Kim H-o, Song S-H, Park S-S, Park T-H, Ahn J-Y, Kim M-K, Choi JP et al (2017) J Clin Neurol (13) 3:227-233. https://doi.org/10.3988/jen.2017.13.3.227

Koralnik IJ, Tyle KL (2020) COVID-19: a global threat to the nervous system. https://doi.org/10.1002/ana.25807

Lahiri D, Ardila A (2020a) COVID-19 pandemic: a neurological perspective. Cureus. April 29 (12)4:e7889. https://doi.org/10.7759/ cureus.788

Lahiri D, Mondal R, Deb S, Shome G, Ganguly U et al (2020) Incidence, clinical presentation, laboratory findings, imaging features and outcome of meningoencephalitis in COVID-19: a systematic review and meta-analysis. PROSPERO CRD42020185571

Lau KK, Yu WC, Chu CM, Lau ST, Sheng B, Yuen KY et al (2004) Possible central nervous system infection by SARS coronavirus. Emerg Infect Dis 10(2):342-344. https://doi.org/10.3201/ eid1002.030638

Li Y, Li H, Fan R et al (2016) Coronavirus infections in the central nervous system and respiratory tract show distinct features in hospitalized children. Intervirology 59(3):163-169. https://doi. org/10.1159/000453066

McAbee GN, Brosgol Y, Pavlakis S, Agha R, Gaffoor M et al (2020) Encephalitis associated with COVID-19 infection in an 11-year-old child. Pediatr Neurol. https://doi.org/10.1016\%2Fj. pediatrneurol.2020.04.013

Morassi M, Bagatto D, Cobelli M et al (2020) Stroke in patients with SARS-CoV-2 infection: case series. J Neurol. https://doi. org/10.1007/s00415-020-09885-2

Morfopoulou S, Brown JR, Davies EG et al (2016) Human coronavirus OC43 associated with fatal encephalitis. N Engl J Med. 375:497498. https://doi.org/10.1056/NEJMc1509458

Moriguchi T, Harii N, Goto J et al (2020) A first case of meningitis/encephalitis associated with SARS-Coronavirus-2. Int J Infect Dis. 94:55-58

Mukherjee D, Sarkar P, Dubey S et al (2020) Ataxia as a presenting manifestation of COVID-19: report of a single case. medRxiv.https://doi.org/10.1101/2020.05.24.20103648

Netland J, Meyerholz DK, Moore S, Cassell M, Perlman S et al (2008) Severe acute respiratory syndrome coronavirus infection causes neuronal death in the absence of encephalitis in mice transgenic for human ACE2 Journal of Virology Jul, 82 (15) 72647275. https://doi.org/10.1128/JVI.00737-08

Packwood R, Galletta G, Tennyson J et al (2020) An unusual case report of COVID-19 presenting with meningitis symptoms and shingles. Clinical Practice and Cases in Emergency Medicine. https://doi.org/10.5811/cpcem.2020.4.47557 
Panariello A, Bassetti R, Radice A et al (2020) Anti-NMDA receptor encephalitis in a psychiatric Covid-19 patient: a case report. Brain, Behaviour, and Immunity 87:179-181

Pierre SZYBA, Toko YRL, Klopfenstein TVGT et al (2020) Encephalopathy in patients with COVID-19: 'Causality or coincidence?' J Med Virol. https://doi.org/10.1002/jmv.26027

Pilotto A et al (2020) The clinical spectrum of encephalitis in COVID-19 disease: the ENCOVID multicentre study. medRxiv. 06.19.20133991

Pilotto A, Odolini S, Masciocchi S et al (2020) Steroid-responsive encephalitis in coronavirus disease 2019 [published online ahead of print, 2020 May 17]. Ann Neurol. https://doi. org/10.1002/ana.25783

Prasad R (1982) Immunoglobulin levels in serum and cerebrospinal fluid in certain viral infections of the central nervous system The Journal of Infectious Diseases, September, 148(3):607. https:// doi.org/10.1093/infdis/148.3.607

Romero-Sánchez CM, Díaz-Maroto I, Fernández-Díaz E et al (2020) Neurologic manifestations in hospitalized patients with COVID-19: the ALBACOVID Registry. Neurology. https://doi. org/10.1212/WNL.0000000000009937

Schattner A, Hadar S, Dubin I et al (2018) Human coronavirus NL63 and acute encephalitis. Ann Infect Dis Epidemiol. 3(2): 1032. ISSN: $2475-5664$

Sureka J, Jakkani RK (2012) Clinico-radiological spectrum of bilateral temporal lobe hyperintensity: a retrospective review Br J Radiol. 85(1017):e782-e792. https://doi.org/10.1259/bjr/ 30039090

Sohal S, Mossammat M (2020) COVID-19 Presenting with seizures. IDCases 20:e00782
Talmor G, Grube JG, Eloy JA, Liu JK, Hsueh WD et al (2020) Nasoseptal flap necrosis after endoscopic skull base surgery in the setting of severe acute respiratory syndrome coronavirus $2 /$ coronavirus 2019. World Neurosurg. https://doi.org/10.1016/j. wneu.2020.05.237

Varatharaj A, Thomas N, Ellul MA et al (2020) Neurological and neuropsychiatric complications of COVID-19 in 153 patients: a UK-wide surveillance study. Lancet Psychiatry. S2215-0366(20)30287-X. https://doi.org/10.1016/ S2215-0366(20)30287-X

Wong PF, Craig S, Newman P et al (2020) A case of rhombencephalitis as a rare complication of acute COVID-19 infection. Clin Med 20:293-294

Ye M, Ren Y, Lv T et al (2020) Encephalitis as a clinical manifestation of COVID-19. Brain Behav Immun 1591:30465-30467

Yeh EA, Collins A, Cohen ME, Duffner PK, Faden H (2004) Detection of coronavirus in the central nervous system of a child with acute disseminated encephalomyelitis. Pediatrics $113(1 \mathrm{Pt}$ 1):e73-e76. https://doi.org/10.1542/peds.113.1.e73

Yin R, Feng W, Wang T et al (2020) Concomitant neurological symptoms observed in a patient diagnosed with coronavirus disease 2019. J Med Virol. https://doi.org/10.1002/jmv.25888

Zubair AS, McAlpine LS, Gardin T, MPP; Farhadian S, Kuruvilla DE, Spudich S et al (2019) Neuropathogenesis and Neurologic Manifestations of the Coronaviruses in the Age of Coronavirus Disease. JAMA Neurol. https://doi.org/10.1001/jamaneurol.2020.2065

Publisher's Note Springer Nature remains neutral with regard to jurisdictional claims in published maps and institutional affiliations. 